\title{
Some Bad News is Good News for Foreign Investors: The Case of Intellectual Property Rights Infringement in China
}

\author{
Icksoo Kim \\ Korea University Business School \\ Korea University \\ 145 Anam-ro, Seongbuk-gu, Seoul, 136-701, Korea \\ Tel. +82 2032901940 \\ Fax +82 2032902541 \\ Email: $\underline{\text { iksu@korea.ac.kr }}$ \\ Eunsuk Hong*** \\ Department of Financial and Management Studies (DeFiMS) \\ SOAS, University of London, \\ Thornhaugh Street, Russell Square, London WC1H 0XG, UK \\ Tel. +44 2078984564 \\ Fax +442878984089 \\ Email: e.hong@soas.ac.uk \\ Jong Kook Shin \\ Newcastle University Business School \\ Newcastle University \\ 5 Barrack Road, Newcastle upon Tyne, NE1 4SE, UK \\ Tel. +4419120816431677 \\ E-mail: jong.shin@ncl.ac.uk \\ $\&$ \\ Laixiang Sun \\ Department of Geographical Sciences \\ University of Maryland \\ 2181 Samuel J. LeFrak Hall, College Park, MD 20742, USA \\ Tel. (301) 4058131 \\ Email: 1sun123@umd.edu
}

$* * *$ Corresponding author 


\section{Some Bad News is Good News for Foreign Investors: The Case of Intellectual Property Rights Infringement in China*}

\section{Executive Summary}

Despite China's attractiveness to foreign investors, intellectual property rights (IPR)

protection in China has not caught up with international standards. This research aims to quantify the relationships between IPR violations, government effectiveness, and foreign direct investment (FDI) inflows in the context of China. Our econometric modeling and estimation based on provincial level data over 2002-2012 show that in an early development stage of law and regulatory enforcement, the bad news of a rising number of IPR dispute cases signals the good news of an improvement in law and regulatory enforcement, which encourages IPR owners to raise legal cases. By contrast, in the later development stage when law and regulatory enforcement has become much more effective, the bad news of a rising number of IPR disputes manifests itself as real bad news. Furthermore, this study confirms that FDI inflows enhance IPR protection through improving government effectiveness and the government effectiveness is one of the key factors promoting FDIs.

Keywords: Foreign Direct Investment, Dual Track System of IPR Enforcement, IPR infringement, Local Protectionism, Government Effectiveness, China

\footnotetext{
* This research was supported by the National Research Foundation of Korea Grant (NRF-2008-362-A00001) and the 2014 KUBS Faculty Research Grant.
} 


\section{Introduction}

China has experienced rapid economic development and growth since the initiation of market reform in 1978 and has emerged as a key player in global trade and financial market. China became the world's largest exporter of goods in 2009 and overtook the US as the world number one trading nation in 2013, with a trade volume over US\$4 trillion (WTO, 2014). According to the latest International Monetary Fund (IMF) figures (IMF, 2014), China also surpassed the US as the world's largest economy in 2014 in terms of GDP based on purchasing power parity (PPP). In 2014, China’s PPP-adjusted GDP reached US\$17.63 trillion or $16.48 \%$ of the world's total, compared with the corresponding US figures of US\$17.4 trillion or $16.28 \%$ of the world's total. Such rapid economic development has made China the world's largest recipient of foreign direct investment since 2002. In 2014, China attracted US\$ 128 billion of FDI (UNCTAD, 2015). Despite China's increased role in the global economy and attractiveness to foreign investors, it has been widely acknowledged that the level of intellectual property rights (IPR) protection in China has not caught up with international standards. This disparity between China's emerged economic power at the global level and its weak enforcement mechanisms for IPR laws at the national level has made IPR protection in China one of the top concerns in the global business community. According to the latest figures, $72 \%, 77 \%$, and $87 \%$ of the total counterfeiting and infringing goods seized at the US, EU, and Japan customs, respectively, came from China in 2012 (US IPR Seizure Statistics 2012, Commission, 2013; Japan Customs, 2013).

This great concern of the global business community in general and multinational enterprises (MNEs) from the OECD countries in particular has stimulated an emerging body of literature dealing with the issue of weak IPR protection in China and the implications for MNEs in the disciplines of law (e.g., Kassner, 2012; Chow, 2010; Rezler, 2010; Sepetys and 
Cox, 2009; Gabriel, 2008) and business management and economics (e.g., Zimmerman and Chaudhry, 2009; Chapa and LeMaster, 2007; Yu, 2007; Hung, 2003). Surprisingly, however, there has been a lack of formal econometric work in the literature to quantify the relationship between IPR violations, government effectiveness, and FDI inflows in the context of Chinaspecific institutional environment. In light of the growing significance of China in the global economy, it is of both academic and policy importance to investigate the interactive relationship between IPR infringement incidence and the government effectiveness and, further, the interactive relationships between FDI activities of MNEs and government effectiveness and IPR infringement disputes in the context of China.

This research aims to fill this important niche. Drawing on insights from broad theoretical literature, this paper develops three analytical models. The first one suggests a non-linear relationship between the observed relative level of infringement claim cases and the level of government effectiveness, where the observed count of infringement cases equals the total number of infringement incidences times the probability of filing a claim with the regulatory authorities. The second model is an extension of the first model by including FDI as an independent variable. It suggests that inward FDI indirectly contributes to a higher level of IPR protection mainly through enhancing government effectiveness, because local governments in China compete with each other to attract FDI and understand that local government effectiveness is attractive for FDI in general and FDI with advanced technology in particular. The third model suggests that the attractiveness of a host region for multinational enterprises (MNEs) is closely associated with the effectiveness of IPR law and regulatory enforcement and the government effectiveness of the regional authority. MNEs prefer to make their investments in host regions with a more transparent and effective institutional framework. A quadratic specification is adopted to test the relationships suggested by these three models. 
The dataset for the testing include the number of patent infringement claim cases under administrative investigation in 30 provinces (including 4 provincial-level municipalities) of China during 2002-2012, the government effectiveness index in 30 Chinese provinces constructed by the World Bank in 2006, and the number of foreign funded enterprises in 30 Chinese provinces during 2002-2012. The Hausman-Taylor estimator is employed to run the econometric estimations because this estimator allows for the timeinvariant regressors (c.f. Government effectiveness) to be correlated with the unobserved individual effects. The estimation results are in line with our expectation. The first set of results confirms an inverted-U shaped curvilinear effect running from government effectiveness to the relative level of the number of infringement claim cases. The second set of results show that FDI inflows modify the relationship between government effectiveness and the relative level of the number of infringement claim cases in a way to contribute to the reduction of the latter mainly through FDI's impact on the level of transparency and effectiveness of institutional framework. The third set of results show that government effectiveness has a direct impact on FDI inflows, indicating that a host region with a better government effectiveness attract more FDI inflows; furthermore, the relative level of the count of infringement claim cases has a positive impact on FDI inflows. These three sets of results are robust for a number of popular control variables and the second set is also robust for alternative measures of FDI inflows.

The rest of the paper is organized as follows. Section 2 outlines the institutional foundation of IPR regimes in China. In section 3, based on analytical discussions on IPR protection, government effectiveness and FDI, we develop three models to characterize the interactive relationships between the number of infringement claim cases, the index of government effectiveness, and FDI inflows. In Section 4, we define the key variables and suggest the best available estimation method - the Hausman-Taylor estimator. In Section 5, 
we estimate the models using the Hausman-Taylor estimator and report the empirical results. Finally, Section 6 discusses the theoretical and policy implications of the findings and presents concluding remarks.

\section{Intellectual Property Rights (IPR) Protection in China}

\subsection{China as a key source of counterfeit goods to the world market}

The recent surge in exports of counterfeits worldwide and in particular, those from China to other countries, has caused many world leading MNCs to declare intellectual property rights (IPR) infringements to be an urgent global business problem (Economist, 2010). It is virtually impossible to accurately estimate the value of infringing goods originating from China, but it is evident that infringing production in China has grown alongside the remarkable growth in the Chinese economy and export (Chow, 2010, Zimmerman and Chaudhry, 2009). In 2012, the US, EU and Japan reported a total of 139,928 seizures of shipments of counterfeit and infringing goods by their customs authorities, which represents more than a five-fold increase from the 24,621 cases in $2003 .^{1}$

China is generally acknowledged as the world's number one source of counterfeit and infringing goods in recent years. For example, the total value of infringing goods seized at the US ports of entry was $\$ 1.26$ billion in 2012 . Of this total, more than $\$ 900$ million, or $72 \%$ of the total, originated from China (US IPR Seizure Statistics 2012). In the same year, infringing products from China accounted for $77 \%$ and $87 \%$ of the total amount seized by the customs authorities of the European Union and Japan respectively (European Commission, 2013;

\footnotetext{
${ }^{1}$ Authors' calculation, based on U.S. Customs and Border Protection Office of International Trade, 2004, 2013; European Commission, 2013; Japan Customs, 2008, 2013.
} 
Japan Customs, 2013). ${ }^{2}$

\subsection{A wide gap between formulation of IPR regimes and its enforcement}

In recent years, it has been observed that the statute laws on IPR in China have been increasingly converging with international standards (Kassner, 2012; Sepetys and Cox, 2009; Gabriel, 2008; Yu, 2007). China joined several international organizations and agreements, and promulgated domestic legislation, including the Trademark Law of the People's Republic of China in 1982 and the Patent Law of the People's Republic of China in 1984. In 2001, China joined the WTO and since then further amended its IPR laws and regulations to comply with the WTO agreement on Trade-Related Aspects of Intellectual Property Rights (TRIPS) (Rezler, 2010; Chapa and LeMaster, 2007). In spite of continuous development of China's intellectual property law following the international standards, the enforcement of these laws has not been consistent across provinces and cities in China and has not met international expectations (Kassner, 2012; Yu, 2007). A wide gap between the formulation of the statute IPR laws and their enforcement in China can be attributed to a combination of (i) regional disparity in economic development (Yu, 2007), and (ii) the federalism-Chinese style, which is characterized as a decentralized, multi-layered, multi-regional governance structure with relatively harder budget constraints for lower level local governments, and interjurisdictional competition (Weingast, Qian, and Montinola, 1995; Cao, Qian, and Weingast, 1999). Regional disparity in economic development implies diverse interests among

\footnotetext{
${ }^{2}$ Based on the assumption that most of the counterfeit and infringing goods exported from Hong Kong were actually produced in China (Chow, 2010), the total value of seized counterfeit and infringing goods exported from China and Hong Kong to the U.S., EU and Japan totalled \$ 1.1 billion, $€ 862.9$ million, and $¥ 18.4$ billion in 2012, which accounted for $84 \%, 87 \%$ and $94 \%$ of all seizures respectively (Authors' calculation, based on U.S. Customs and Border Protection Office of International Trade, 2013 on slides 10-11; European Commission, 2013: p.7 and p.18; Japan Customs, 2013, IMPORT 9 in p.8 ).
} 
provincial and municipal governments with respect to enforcement of IPR laws. For some local governments, intellectual property infringement is in fact beneficial to their local economies because it can create new jobs and tax revenues (at least) in the short term (Chow, 2010; Tao, 2007). With local protectionism under the China-specific decentralized governance structure, some local governments with relative low levels of economic development prioritize the protection of local interest above the national interest of complying IPR laws with the international standards. Therefore, these local governments are less likely to impose strict enforcement measures against alleged infringement cases (Chow, 2010; Gabriel, 2008; Tao, 2007; Cox and Sepetys, 2005; Wang, 2004).

\section{Theoretical Background and Model Development}

\subsection{Influence of government effectiveness and inward FDI on patent infringement claims in China}

Following the logic of gradualist reform, China has adopted a dual track system of IPR enforcement (Kassner, 2012; Cox and Sepetys, 2005; Wang, 2004). The first track is the judicial enforcement process, which involves filing a complaint to a judicial civil court. The second track is the administrative enforcement process, which is regarded as one of the distinctive features of China's IPR protection regime. On the administrative track, the administrative agencies investigate infringement cases and penalize the guilty party. Due to the legacies of China's centrally planned economy system, the administrative proceedings have played arguably the most important role in IPR enforcement (Kassner, 2012). Therefore, the number of administrative infringement claim cases under investigation in a province can be regarded as an informative indicator of the extent to which the province commits to combat IPR infringements. Table 1 reports the spatial distribution of patent infringement 
claimed through the administrative track by three provincial groups for 2002-2012. From 2002 to 2012, the number of patent disputes handled by local IP administrative authorities totalled 14,451 cases. In terms of geographical distribution, more than $70 \%$ of patent infringement was claimed in the coastal region in 2002. While the coastal region retained its dominant position in infringement claims, its share in the national total decreased by 21.64 percentage points from $72.34 \%$ in 2002 to $50.70 \%$ in 2011 . The central region took 18.72 percentage points of the share from the coastal region. The west basically kept the same growth pace with that of the national total, swinging between $11.15 \%$ and $17.89 \%$. The coefficient of variations (CV) across the three regions shows a decline trend and decreased by about 50\% from 2002 to 2012, implying a tendency of reduced disparity.

Insert Table 1 about here

To quantify the influence of government effectiveness on IPR enforcement, the most relevant and available data in China is the number of patent infringement cases claimed, claim count. It can be decomposed into a product of the total infringement count (TIC) and the probability of filing a claim. This decomposition captures two distinct aspects of patent infringement cases. TIC can be considered as the "supply side" of the infringement claims as it defines the maximum possible number of infringement claims. The level of the supply side activity would be affected by the usual business environments such as the market size, the expected benefits of those business activities which are based on patent piracy, and the potential punishment if being caught by government enforcement agencies. It would be natural to expect TIC to be negatively correlated with the law and regulatory enforcement as 
tighter enforcement will increase the probability of being caught, getting unfavorable ruling, and paying damage compensation. With respect to the probability of filing a claim, please note that not all patent infringement cases are brought to the attention of regulatory bodies. Some cases are simply not caught on the radar of patent holders. Even if patent holders know the existence of solid infringement cases, however, they may not want to bring such cases to the government or the court because the costs of legal action may exceed the expected benefits. Generally speaking, under a weaker enforcement system, a case is less likely to be accepted and then ruled favorably to the patent holders. This will lead to a lower probability of filing claims. In recognizing this, we hypothesize that the "demand side" of piracy claims is positively correlated with the law and regulatory enforcement.

Given that Claims Count is the product of TIC and the probability of filing a claim and the two multiplying factors have opposite correlation signs with respect to the effectiveness of law and regulatory enforcement, we do not know which effect would dominate a priori. Therefore, our first model allows for a non-linearity specification of the relationship between government effectiveness and the number of patent infringement claims.

While it is widely acknowledged that IPR protection is a driving force for attracting foreign investors (Section 3.2 will review this line of literature), there has been a shortage of research attention paid to the effect of FDI activities on the level of IPR protection. Our first model provides a convenient base for quantifying this important effect and thus enriches the literature. By introducing FDI and its interactive variables with government effectiveness in the first model, we can link FDI inflows to observed infringement claim numbers and government effectiveness, and explore whether inward FDI influences IPR infringement claim patterns through inducing a higher level of government effectiveness. This is our second model. 


\subsection{Influence of IPR protection and government effectiveness on activities of foreign funded enterprises in China}

Since the seminal work of La Porta, Lopez-de-Silanes, Shleifer and Vishny (1997, 1998), a growing body of research in political economy and finance has suggested legal origin, whether a country follows common laws or civic laws, has persistent impacts on various dimensions of legal institutions, which in turn leads to systematic difference in economic performance. La Porta et al. $(1997,1998)$ argues that common law countries tend to have better investor protection, measured by quality of legal rules and law enforcement than civil law countries, and thus are more likely to house broader equity and debt markets. Djankov et al. (2007) shows that a country with better creditor protection is more likely to have developed private credit market. Djankov et al. (2008) demonstrate that stronger debt enforcement is positively correlated with GDP per capita and debt market development. These studies find evidence that effective legal rules and law enforcement are conducive to protection of outside investors' rights, which in turn promotes external financing.

In the international business literature, recent empirical evidence has shown that effective institutional environment in a host country is an important determinant of foreign direct investment inflows (Globerman and Shapiro, 2003; Seyoum, 2009; Mengistua and Adhikary, 2011; Hsu and Tiao, 2015). Using international data on FDI inflows and outflows, Globerman and Shapiro (2002) find that good governance affects the security of property rights, transparency of government and legal processes and thus attract more FDI inflows. Also, using a probit model with data on outward FDI from the United States, Globerman and Shapiro (2003) argue that good institutions in host countries establish a conducive climate to the multinational companies from the USA. By examining the effects of the World Bank's notion of good governance on FDI inflows in 15 Asian countries, Mengistua and Adhikary 
(2011) find that political stability and absence of violence, government effectiveness, rule of law, and control of corruption are the key determinants of FDI inflows. These findings highlight the importance of improving the domestic governance environment for attracting FDI inflows, which is also confirmed by Seyoum (2009), finding that strong formal institutions in host countries attract more FDI flows. Hsu and Tiao (2015) investigate the relationship between patent rights protection and inward FDI in eleven Asian countries and their empirical results indicate that the strengthening of patent rights protection has a positive impact on inward FDI in Asian countries.

In light of the above discussion, it seems that we can simply hypothesize that the more effective IPR protection and government is associated with more active foreign investment. However, an in-depth observation of the Chinese context suggests more complex and interesting relationships between the level of IPR protection and that of FDI activities. On one hand, one may argue that a larger number of claims may signal weak IRP protection, which in turn deters foreign firm's activities. If it is true, there will be a negative relationship between the number of patent infringement cases and the level of FDI activities. On the other hand, our discussion in this and previous subsection has implied that the effect of claim counts on FFE activities may differ owing to the regional heterogeneity in IPR protection. For example, in a more developed region with stronger IPR protection, it is plausible that the demand for (or probability of filing) claims is already high. In such a regulatory environment, an increase in claim counts can be interpreted as an increase in IPR infringement, thus representing a negative signal to potential foreign entrepreneurs. By contrast, in a less developed region with a weak IPR protection regime, the total infringement incidents might be already very high. An increase in claim counts here can indicate that the existing IPR entrepreneurs are keener to raise claims upon infringement. This signals that they believe the enforcement of law and regulations in the region is more trustworthy than before, and thus 
represents good news for potential foreign investors in the region. To test this idea, we introduce Coast dummy which takes the value of 1 for the observations from the coastal region and zero otherwise. ${ }^{3}$ In general, the coastal (non-coastal) areas have better (worse) enforcement of law and regulations. ${ }^{4}$ Thus, we expect a positive association of Claim Count and level of FDI activities in the non-coastal region and a negative association of the two variables in the coast region.

\section{Data, Variables, and Estimation Methods}

\subsection{Dependent Variables}

The dependent variable in our first and second models is the relative level of patent infringement cases claimed in region $i$ and year $t\left(\operatorname{Claim}_{i t}\right)$, which is measured as the ratio of patent infringement cases claimed in region $i$ and year $t$ to the national total number of patent infringement cases claimed in year $t$, and is presented in percentage. To measure business activity of MNEs in China which is the dependent variable in our third model, we use the logarithm of the number of foreign funded enterprises in region $i$ and year $t\left(\ln F F E_{\text {number,it }}\right)$. Data used in our estimations is a panel of 30 provinces and municipalities over the period 2002-2012. Among all 31 provinces and municipalities in China, Tibet is excluded mainly because of data unavailability. The number of patent infringement cases claimed at the provincial level is obtained from Patent Statistical Yearbook published by the State Intellectual Property Office of China (SIPO, www.gov.cn). The data source for foreign

\footnotetext{
${ }^{3}$ The coastal regions include Beijing, Tianjin, Hebei, Liaoning, Shanghai, Jiangsu, Zhejiang, Fujian, Shandong, Guangdong, and Hainan.

4. We use coastal vs. non-coastal classification to sort the regions according to the maturity of law and regulatory enforcement. In unreported robustness tests, we have also performed similar regressions using different dummy variables such as high vs. low government effectiveness, etc. Our qualitative results are robust to these alternative specifications.
} 
funded enterprises in China is obtained from China Statistical Yearbook (various years) published by the State Bureau of Statistics in China.

\subsection{Independent Variables}

The variable representing the effectiveness of law and regulatory enforcement is the government effectiveness index in the region $i$ and year $t\left(\right.$ Effect $\left._{i t}\right)$, which is measured as the average of city-level government effectiveness index across cities in province $i$ and year $t$ $(t=2006)$. The information on local government effectiveness in China is obtained from World Bank (2006). It was based on a large survey of 120 cities and 12,400 firms conducted in 2006 and has been the most comprehensive survey on government effectiveness in China so far. Since the unit of analysis we adopt in this study is province, we aggregate and organize the survey data into 30 provinces (Table 2). Following the discussion of Section 3.1, we take both Effect $_{i t}$ and its square to capture the possible non-linear effect of the effectiveness of law and regulatory enforcement on the relative level of patent infringement claims. Please note that $\ln F F E_{\text {number,it }}$ will also be an independent variable in our second model.

Insert Table 2 about here

\subsection{Control Variables}

Although we suggest the importance of the law and regulatory enforcement in determining the level of patent infringement and business activities of MNEs, a number of other factors have been identified in the literature as important determinants of piracy activity levels and 
FDI. To take into account the effects of those factors, we incorporate a comprehensive set of control variables in our empirical estimations. First, we employ the measures and proxies involving regional market size, regional output of knowledge production, and regional openness level. In addition, we also include yearly and regional fixed effects to address unobserved time and regional specific characteristics.

Regional market size is measured by the logarithm of gross regional product in the region $i$ and year $t$ and denoted as $\ln G R P_{i t}$. Regional output of knowledge production is defined as the relative level of patent applications in the region $i$ and year $t$ ( Patent $\left._{i t}\right)$, which is measured as the ratio of patent application numbers in the region $i$ and year $t$ to the national total number of patent applications in year $t$, and is presented in percentage. The degree of openness $\left(\right.$ Open $\left._{i t}\right)$ is proxied by the ratio of the total amount of trade (the sum of total export and import value by place of destination or origin) in region $i$ and year $t$ to the gross regional product in region $i$ and year $t$ and is presented in percentage. Data sources for constructing all above control variables are China Statistical Year Book (various years).

Table 3 presents the summary statistics and the correlation matrix of the variables employed in our empirical regressions.

Insert Table 3 about here

\subsection{Econometric Model and Estimation Methods}


To test the existence of the non-linear relationship between the relative level of patent infringement claims and government effectiveness with the above-discussed robustness control, we formulate our first model as follows:

$$
\begin{aligned}
\text { Claim }_{i t} & =\beta_{0}+\beta_{1} \text { Effect }_{i, 2006}+\beta_{2} \text { Effect }_{i, 2006}^{2}+\beta_{3} \ln \text { GRP }_{i t}+\beta_{4} \text { Patent }_{i t} \\
& +\beta_{5} \text { Open }_{i t}+u_{i}+v_{t}+\varepsilon_{i t}
\end{aligned}
$$

where $u_{i}$ and $v_{t}$ capture region- and year-specific effects, respectively, and $\varepsilon_{i t}$ is an error term. Our second model is specified as a natural extension of Eq (1):

$$
\begin{aligned}
\text { Claim }_{i t} & =\beta_{0}+\beta_{1} \text { Effect }_{i, 2006}+\beta_{2} \text { Effect }_{i, 2006}^{2}+\beta_{3} F F E_{\text {number }, i t}+\beta_{4} \ln G R P_{i t} \\
& +\beta_{5} \text { Patent }_{i t}+\beta_{6} \text { Open }_{i t}+\beta_{7} \text { Effect }_{i, 2006} * F F E_{\text {number }, i t} \\
& +\beta_{8} \text { Effect }_{i, 2006}^{2} * F F E_{\text {number }, i t}+u_{i}+v_{t}+\varepsilon_{i t}
\end{aligned}
$$

We then formulate our third model as follows to test the relationship between MNEs' business activities, relative level of patent infringement claims and government effectiveness with the same set of robustness control as in Eq (1):

$$
\begin{gathered}
\text { FFE }_{\text {number }, i t}=\beta_{0}+\beta_{1} \text { Claim }_{i t}+\beta_{2} \text { Effect }_{i, 2006}+\beta_{3} \ln \text { GRP }_{i t}+\beta_{4} \text { Patent }_{i t} \\
+\beta_{5} \text { Open }_{i t}+u_{i}+v_{t}+\varepsilon_{i t} \\
\begin{aligned}
\text { FFE }_{\text {number }, i t} & =\beta_{0}+\beta_{1} \text { Claim }_{i t}+\beta_{2} \text { Claim }_{i t} * \text { Coast }+\beta_{3} \text { Effect }_{i, 2006}+\beta_{4} \ln \text { GRP P }_{i t} \\
& +\beta_{5} \text { Patent }_{i t}+\beta_{6} \text { Open }_{i t}+u_{i}+v_{t}+\varepsilon_{i t}
\end{aligned}
\end{gathered}
$$

Panel data method is used to control unobserved individual effects in the data. To choose fixed or random effects, the Hausman test is conducted and it reveals that the unobserved individual effects are correlated with the regressors. Therefore, the fixed effects estimator is the preferred model. However, one of the main disadvantages of the fixed effects estimator is that it wipes out the effects of time-invariant regrossors (e.g., Effect $_{i, 2006}$ ). Using Monte Carlo experiments, Baltagi, Bresson, and Pirotte (2003) show that the random effects model leads to misleading inference if some regressors are correlated with the individual effects. We use the Hausman-Taylor model (1981) to address this issue. By using the 
individual means of exogenous regressors as instruments for the time invariant regressors, the Hausman and Taylor (1981) estimator recaptures the estimates of time-invariant regressors under a model where some of the regressors are correlated with the individual effects. In our empirical exercises, however, we report both random effect and Hausman-Taylor estimations for Eq. (1) and both fixed effect and Hausman-Taylor estimations for Eqs. (2), (3) and (3') to show the advantage of Hausman-Taylor methods and also the robustness of our key results with respect to estimator choice.

\section{Empirical Results}

\subsection{Impact of government effectiveness on patent infringement claims in China}

Eq. (1) is estimated by the random effects and Hausman-Taylor estimators, respectively. The estimation results are presented in Models 1-4 of Table 4. Let us first look at the results of Models 1 and 3, which focus on the linear effect of Effect $_{i, 2006}$ only. The coefficient estimations of $E_{f f e c t}{ }_{i, 2006}$ produced by random effects and Hausman-Taylor estimators are statistically insignificant and this suggests that the non-linear effects of government effectiveness on claim counts may have been cancelled out in the linear setting. Models 2 and 4 investigate the non-linear effect hypothesis using random-effect and Hausman-Talyor methods. The results support an inverted U-shaped relationship between government effectiveness and the relative level of infringement claims. For instance, the coefficients of Effect $_{i, 2006}\left(\hat{\beta}_{1}=0.387\right)$ and Effect $_{i, 2006}^{2}\left(\hat{\beta}_{2}=-0.003\right)$ support an inverted U-shaped relationship between law enforcement effectiveness and the relative level of infringement claims. This result suggests that in the early development stage of law and regulatory enforcement, the marginal effect of tighter enforcement on the probability of encouraging 
patent owners to raise cases is greater than that on reducing the violations of patent rights; as a result, tighter enforcement is associated with a higher level of infringement claims. It is in this sense we say that such bad news as a higher level of infringement claims is good news for foreign investors because it signals an improvement in the law and regulatory enforcement in the region. By contrast, in the latter development stage when the effectiveness of law and regulatory enforcement has reached a high level, the marginal effect of tighter enforcement on reducing the violations of patent rights is greater than that on the probability of filing a claim and thus tighter enforcement will lead to a reduced number of violation cases.

With regard to control variables in Models 1-4, their coefficients all are positive and statistically significant. This implies that a region with a larger regional market size ( $\left.\ln G R P_{i t}\right)$, a greater regional output of knowledge production $\left(\right.$ Patent $\left._{i t}\right)$, and a greater degree of openness $\left(\right.$ Open $\left._{i t}\right)$ is likely to experience a relatively higher level of infringement claim cases.

Insert Table 4 about here

\subsection{Moderating effect of FDI activities on the relationship between patent infringement claims and government effectiveness in China}


Model 5 in Table 4 tests if activities of foreign funded enterprises have a direct impact on patent infringement. ${ }^{5}$ The coefficient of $\ln F F E_{\text {number, it }}$ is statistically insignificant and this result does not suggest a direct impact of FDI inflows on infringement claim numbers. Considering our discussions on the relationship between inward FDI and government effectiveness and the non-linear relationship between government effectiveness and infringement claim numbers (Section 3), the impact of inward FDI on infringement claim numbers might be channelled through the direct relationship between government effectiveness and infringement claims. Model 6 addresses this concern with the help of the interaction terms Effect $_{i, 2006} * \ln F F E_{\text {number , it }}$ and Effect ${ }_{i, 2006}^{2} * \ln F F E_{\text {number, }, \text { t }}$. In Model 6, while the coefficients on $\ln F F E_{\text {number, it }}$ and $\ln F F E_{\text {number, it }}^{2}$ remain statistically insignificant, the coefficients of the two interactive terms are significant. More interestingly, the moderating effect of FDI activities does not alter the inverted U-shaped pattern of the basic relationship between government effectiveness and IPR protection, but pushes the curve rightwards, which is equivalent to an improvement in government effectiveness in the basic relationship. It is in this way that FDI activities make a contribution to the improvement in IPR protection. To ensure the robustness of this set of empirical findings, we conducted robustness tests using alternative measurements for the activities of foreign funded enterprises in China. The alternative measurements include the logarithm of the amount of investment of foreign funded enterprises in region $i$ and year $t\left(\ln F F E_{\text {investment,it }}\right)$ and the amount of registered capital of foreign funded enterprises $\left(\ln F F E_{\text {Capitalit }}\right)$ in region $i$ and year

\footnotetext{
${ }^{5}$ Because of high correlation between $\ln F F E_{\text {number, it }}$ and $\ln G R P_{i t}$, we do not include the latter in Models 5 and 6.
} 
$t$. The robustness tests generate statistically equivalent results to our main findings reported in Models 5 and 6 in Table $4 .^{6}$

\subsection{Impact of government effectiveness on activities of foreign funded enterprises in}

\section{China}

Eqs. (3) and (3') are estimated by fixed effects and Hausman-Taylor estimators. The estimation results are presented in Table 5. Models 1-3 in Table 5 test the impact of claim cases $\left(\right.$ Claim $\left._{i t}\right)$ and government effectiveness ( Effect $\left.{ }_{i, 2006}\right)$ separately. Model 1 examines the role of the claim variable without the coastal region dummy and using the fixed effect approach. Not surprisingly, the coefficient on claims count is statistically insignificant. As hinted in section 3.2, it is possible that the signs of the coefficient on claim cases are different across regional zones with different effective levels of law and regulatory enforcement. In the presence of such disparity, the average effect could become insignificant. Model 2 addresses this concern with the help of the coastal area dummy. In Model 2, the coefficient of Claim $_{i t}$ variable is significantly positive and the coefficient of Claim $_{i t} \times$ Coast $_{\text {is negative }}$ (with a $p$ value $=0.105$ ). Consistent with our expectation in Section 3.2, these results indicate that a higher level of claims count number in the coastal provinces is associated with a lower level of FDI activities and the opposite relationship holds in the inland regions. This contrast suggests that an increase in claim counts in different types of regions sends different signals to potential foreign investors. In inland provinces where the base-number of total infringement case has already been relatively high, more claim-counts would mean a higher probability of filing claims, which reflects the incumbents' confidence that the law and regulatory enforcement in the region is improving. This is good news to foreign investors. On

\footnotetext{
${ }^{6}$ These robustness test results are available upon request.
} 
the contrary, the coastal regions have a relatively effective enforcement system, which would lead to a higher probability of filing claims. Thus, an increase in claim counts in coastal regions can be a result of increasing infringement activities and this comes as bad news. In

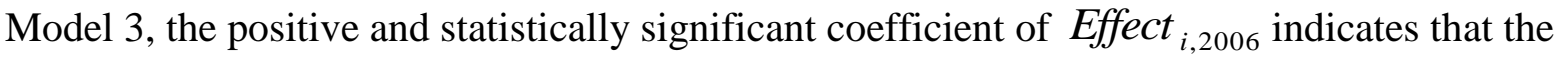
number of foreign funded firms is positively related to the level of regional government effectiveness, consistent with the literature.

Models 4 and 5 assess the effect of both Claim $_{i t}$ and Effect ${ }_{i, 2006}$ jointly. Consistent with the results from Model 1, the coefficient of Claim $_{i t}$ is insignificant when regional disparity (coastal vs inland regions) is not accounted for. The coefficient of Effect $_{i, 2006}$ in Model 4 is significantly positive but the magnitude of the marginal effect is weaker than that of Model 3 (0.005 vs. 0.021). Nevertheless, when we take into account regional disparity in the effects of Claim $_{i t}$ by including an interaction term $\left(\right.$ Claim $_{i t} \times$ Coast $)$, the coefficients of both $\operatorname{Claim}_{i t}(\beta=0.020)$ and $\operatorname{Claim}_{i t} \times \operatorname{Coast}(\beta=-0.024)$ become statistically significant even if the quality of government effectiveness and other influential factors are controlled for. Again, these results support our expectation in Section 3.2. The coefficients of Effect ${ }_{i, 2006}$ in Models 3-5 are consistently positive and statistically significant as conventionally expected. Turning to control variables, their coefficients are positive and statistically significant across all models in Table 5, except the coefficient of Patent $_{i t}$ which is statistically insignificant in all 5 models.

Insert Table 5 about here 


\section{Discussions and Conclusions}

Despite an emerging body of literature on the issue of weak and uneven IPR protection in China, there has been a lack of econometric research to quantitatively assess the relationship between IPR violations and government effectiveness and further the role of FDI inflows in their relationship and their impact on FDI inflows in the context of China. This study has addressed this challenge and thus filled an important niche in the literature.

This study takes into consideration infringement disputes, government effectiveness and inward FDI in the context of China's institutional environment and develops three models. The first model addresses the non-linear relationship between the relative level of infringement claim cases and the effectiveness level of law and regulatory enforcement across provinces in China. The second model features the moderating role played by FDI activities in improving government effectiveness and law enforcement. The third model characterises the important role played by government effectiveness and law enforcement in attracting foreign investors. The empirical estimation of the third model also reveals that regional disparity in the effectiveness of law and regulatory enforcement leads to different signalling effects of IPR infringement claim cases to foreign investors.

Because one of the key independent variables, government effectiveness $\left(\right.$ Effect $\left._{i, 2006}\right)$ is time-invariant and some of the independent variables are correlated with the individual effects, we employ the Hausman-Taylor method to estimate our panel-data models and to detect the non-linear relationship between the relative level of infringement claim cases and the effectiveness level of law and regulatory enforcement across provinces in China. Using the number of patent infringement claim cases under administrative investigation and the number of foreign funded enterprises in 30 provinces of China during 2002-2012 and the government effectiveness index in 30 Chinese provinces constructed by 
the World Bank in 2006, the estimation results support the specifications of our three models and are consistent with our analytical expectation. The results show that the relationship between government effectiveness and the relative level of infringement claim cases is nonlinear and exhibits an inverted-U shaped effect. This result suggests that in an early development stage of law and regulatory enforcement, the bad news of a rising number of IPR dispute cases signals the good news of an obvious improvement in the effectiveness of law and regulatory enforcement which encourages patent owners to raise legal cases. By contrast, in the later development stage when the law and regulatory enforcement has become relatively much more effective, the bad news of a rising number of IPR dispute cases does manifest itself as real bad news. In addition, this study confirms that the FDI activities contribute to better IPR protection through improving government effectiveness and the government effectiveness is one of the key factors promoting FDI activities.

Our finding offers an interesting policy implication. Suppose that policy makers in developing countries/regions consider implementing more stringent IPR enforcement to attract more foreign investment with advanced technology. It is highly likely that such an implementation will lead to an initial increase in IPR claims counts, which may become news headlines. Our findings suggest that the policy makers should focus on improving the effectiveness of law and regulatory enforcement, rather than worrying about an initial increase in IPR claim counts or even deliberately covering-up IPR infringement cases, because intelligent investors will read such headlines as good news and become more willing to invest in the country/region.

In addition to revealing the above insight, this study also contributes to the international business literature by quantitatively modelling the moderating effect of FDI activities on the relationship between government effectiveness and the IPR infringement claim cases, and the effects of government effectiveness on the IPR infringement claim 
numbers and FDI inflows. Our finding suggests that FDI inflows actually enhance IPR protection by improving government effectiveness. This finding encourages foreign investors to pay more attention to the agglomeration effect of FDI in promoting government effectiveness and furthermore in IPR protection. Our modelling framework and the associated empirical testing methods are clearly applicable to similar data from other countries. Future research in this direction would be able to check the extent to which the findings of this research can be generalized.

Two limitations of this study are worth mentioning. First, the government effectiveness index (World Bank, 2006) this study has adopted is only available for one year. Although this index is the most comprehensive and reliable so $\operatorname{far}^{7}$ and the issue of timeinvariance variable in regression model can be addressed by Hausman-Taylor estimator, it might not be able to capture the effect of government effectiveness over time. Future research could examine this issue when updated government effectiveness index becomes available across provinces and also over time. Second, the number of infringement claim cases this study has used is based on patent infringement only and do not cover other sources of infringement such as counterfeiting goods, trademark, copyrights etc. Future research should work with various sources of infringement.

\footnotetext{
${ }^{7}$ Please note two potential problems of employing firm-level survey data: nonresponse and false response to politically sensitive issues (Jensen, Li and Rahman, 2010).
} 


\section{References}

Baltagi, B.H., Bresson, G. \& Pirotte, A. (2003). Fixed effects, random effects or HausmanTaylor? A pretest estimator. Economics Letters, 79(3), 361-369.

Cao, Y., Qian, Y. \& Weingast, B.R. (1999). From federalism, Chinese style to privatization, Chinese style. Economics of Transition, 7(1), 103-131.

Chapa, O. \& LeMaster, J. (2007). Chinese intellectual property rights? Know before you go. Thunderbird International Business Review, 49(5), 567-590.

Chow, Daniel C.K. (2010). Anti-Counterfeiting Strategies of Multi-National Companies in China: How a Flawed Approach is Making Counterfeiting Worse. Georgetown Journal of International Law, 41, 749-779.

Cox, A. \& Sepetys, K. (2005). Intellectual Property Rights Protection in China: Litigation, Economic Damages, and Case Strategies. In G.K. Leonard \& L.J. Stiroh (eds.), Economic Approaches to Intellectual Property: Policy, Litigation and Management. National Economic Research Associates, Inc.

Djankov, S., McLiesh, C. \& Shleifer, A. (2007). Private credit in 129 countries. Journal of financial Economics, 84(2), 299-329.

Djankov, S., Hart, O., McLiesh, C. \& Shleifer, A. (2008). Debt Enforcement around the World. Journal of Political Economy, 116(6), 1105-1150.

The Economist (2010). The Spread of Counterfeiting: Knock-offs Catch On. Mar. 4. 2010, http://www.economist.com/node/15610089.

European commission (2013). Report on EU customs enforcement of intellectual property rights: Results at the EU border 2012. Luxemburg: Publications Office of the European Union,

http://ec.europa.eu/taxation_customs/resources/documents/customs/customs_controls/counter feit_piracy/statistics/2013_ipr_statistics_en.pdf.

Gabriel, R.M. (2008). The Patent revolution: Proposed Reforms in Chinese Intellectual Property Law, Policy, and Practice Are the Latest Step to Bolster Patent Protection in China. Asian-Pacific Law \& Policy Journal, 9(2), 323-355.

Globerman, S. \& Shapiro, D. (2002). Global foreign direct investment flows: The role of governance infrastructure. World Development, 30(11), 1899-1919.

Globerman, S., \& Shapiro, D. (2003). Governance infrastructure and US foreign direct investment. Journal of International Business Studies, 34(1), 19-39.

Hausman, J.A. \& Taylor, W.E. (1981). Panel Data and Unobservable Individual Effects. Econometrica, 49(6), 1377-1398.

Hsu, J. \& Tiao, Y.-E. (2015). Patent rights protection and foreign direct investment in Asian 
countries. Economic Modelling, 44, 1-6.

Hung, C.L. (2003). The business of product counterfeiting in China and the post-WTO membership environment. Asia Pacific Business Review, 10(1), 58-77.

International Monetary Fund (IMF) (2014). World Economic Outlook Database. October 2014 edition, https://www.imf.org/external/pubs/ft/weo/2014/02/weodata/index.aspx.

Japan Customs (2008). 2007 Seizure Statistics of IPR Border Enforcement, Tokyo. http://www.customs.go.jp/mizugiwa/chiteki/pages/statistics/statistics2007.pdf

Japan Customs (2013). 2012 Seizure Statistics of IPR Border Enforcement, Tokyo. http://www.customs.go.jp/mizugiwa/chiteki/pages/statistics/statistics2012.pdf

Jensen, N. M., Li, Q. \& Rahman, A. (2010). Understanding corruption and firm responses in cross-national firm-level survey. Journal International Business Studies, 41(9), 1481-1504.

Kassner, G. (2012). China's IP Reform: State Interests Align with Intellectual Property Protection (Again). JOLT Digest, April.

La Porta, R., Lopez-de-Silanes, F., Shleifer, A. \& Vishny, R.W. (1997). Legal determinants of external finance. Journal of finance, 52(3), 1131-1150.

La Porta, R., Lopez-de-Silanes, F., Shleifer, A. \& Vishny, R.W. (1998). Law and finance. Journal of political economy, 106(6), 1113-1155.

Mengistua, A.A. \& Adhikary, B.K. (2011). 'Does good governance matter for FDI inflows? Evidence from Asian economies. Asia Pacific Business Review, 17(3), 281-299.

Rezler, P. (2010). Breaking through the Great Wall: Problems of Enforcement of Intellectual Property Rights in China. Touro International Law Review, 14(1), 194-259.

Sepetys, K. \& Cox, A.J. (2009). 'Intellectual Property Rights Protection in China: Trends in Litigation and Economic Damages', NERA Economic Consulting.

Seyoum, B. (2009). 'Formal institutions and foreign direct investment. Thunderbird International Business Review, 51(2), 165-181.

Tao, J. (2007). Problems and New Developments in the Enforcement of Intellectual Property Rights in China. In P. Torremans, H. Shan \& J. Erauw (Eds.), Intellectual Property and TRIPS Compliance in China - Chinese and European Perspectives (pp. 107-124). Cheltenham: Edward Elgar Publishing.

U.S. Customs and Border Protection Office of International Trade (2004). Intellectual Property Rights Seizure Statistics 2003, http://www.cbp.gov/linkhandler/cgov/trade/priority_trade/ipr/seizure/fy2003_final_stats.ctt/f y2003_final_stats.pdf.

U.S. Customs and Border Protection Office of International Trade (2013). Intellectual 
Property Rights Seizure Statistics 2012,

http://www.cbp.gov/linkhandler/cgov/trade/priority_trade/ipr/seizure/fy2012_final_stats.ctt/f y2012_final_stats.pdf.

UNCTAD (2015), Global Investment Trends Monitor. No. 18, 28 January 2015.

Wang, L. (2004). Intellectual property protection in China. The International Information \& Library Review, 36(3), 253-261.

Weingast, B.R., Qian, Y. \& Montinola G. (1995). Federalism, Chinese Style: The Political Basis for Economic Success in China. World Politics, 48(1), 50-81.

World Bank (2006), China - Governance, investment climate, and harmonious society: competitiveness enhancement for 120 cities in China, Report No. $37759-\mathrm{CN}$.

World Trade Organization (WTO) (2014), International Trade Statistics 2014, http://www.wto.org/its2014.

Yu, P.K. (2007). Intellectual Property, Economic Development, and the China Puzzle. In D. J. Gervais (ed.) Intellectual Property, Trade and Development: Strategies to Optimize Economic Development in a TRIPS Plus Era. Oxford University Press, Oxford (pp. 173-220).

Zimmerman, A. \& Chaudhry, P.E. (2009). Protecting Intellectual Property Rights: The Special Case of China. Journal of Asia-Pacific Business, 10(4), 308-325. 
Table 1. Patent infringement cases claimed in China

\begin{tabular}{|c|c|c|c|c|c|c|c|c|c|}
\hline \multirow{2}{*}{ Year } & \multicolumn{2}{|c|}{ Coast } & \multicolumn{2}{|c|}{ Central } & \multicolumn{2}{|c|}{ West } & \multicolumn{2}{|c|}{ China } & \multirow{2}{*}{$\begin{array}{c}\text { Coefficient of } \\
\text { variation among } \\
\text { coast, central and } \\
\text { west regions }\end{array}$} \\
\hline & Cases & $(\%)$ & Cases & $(\%)$ & Cases & $(\%)$ & Cases & $(\%)$ & \\
\hline 2002 & 1,012 & $(72.34)$ & 231 & (16.51) & 156 & $(11.15)$ & 1,399 & (100) & 1.02 \\
\hline 2003 & 926 & $(63.95)$ & 303 & (20.93) & 219 & $(15.12)$ & 1,448 & (100) & 0.80 \\
\hline 2004 & 919 & (64.99) & 315 & $(22.28)$ & 180 & (12.73) & 1,414 & (100) & 0.83 \\
\hline 2005 & 870 & (63.97) & 313 & (23.01) & 177 & (13.01) & 1,360 & (100) & 0.81 \\
\hline 2006 & 780 & (63.57) & 265 & (21.60) & 182 & (14.83) & 1,227 & (100) & 0.79 \\
\hline 2007 & 635 & $(64.40)$ & 199 & (20.18) & 152 & (15.42) & 986 & (100) & 0.81 \\
\hline 2008 & 686 & $(62.82)$ & 279 & (25.55) & 127 & (11.63) & 1,092 & (100) & 0.79 \\
\hline 2009 & 573 & $(61.15)$ & 211 & $(22.52)$ & 153 & (16.33) & 937 & (100) & 0.73 \\
\hline 2010 & 547 & (50.79) & 359 & (33.33) & 171 & (15.88) & 1,077 & (100) & 0.52 \\
\hline 2011 & 652 & $(50.70)$ & 453 & (35.23) & 181 & (14.07) & 1,286 & (100) & 0.55 \\
\hline 2012 & 1,313 & (59.01) & 514 & (23.10) & 398 & (17.89) & 2,225 & (100) & 0.67 \\
\hline
\end{tabular}

Note: Coast Region includes Guangdong, Jiangsu, Shandong, Shanghai, Fujian, Zhejiang, Liaoning, Beijing, Tianjin, Hebei, Hainan; Central Region includes Guangxi, Hubei, Hunan, Jiangxi, Henan, Anhui, Heilongjiang, Jilin, Shanxi, Inner Mongolia; West Region includes Chongqing, Sichuan, Shaanxi, Yunnan, Gansu, Guizhou, Qinghai, Xinjiang, Ningxia, Tibet.

Source: Calculated by authors based on Patent Statistical Yearbook, 2002-2013. 
Table 2. Cities surveyed and average of government effectiveness index at provincial level

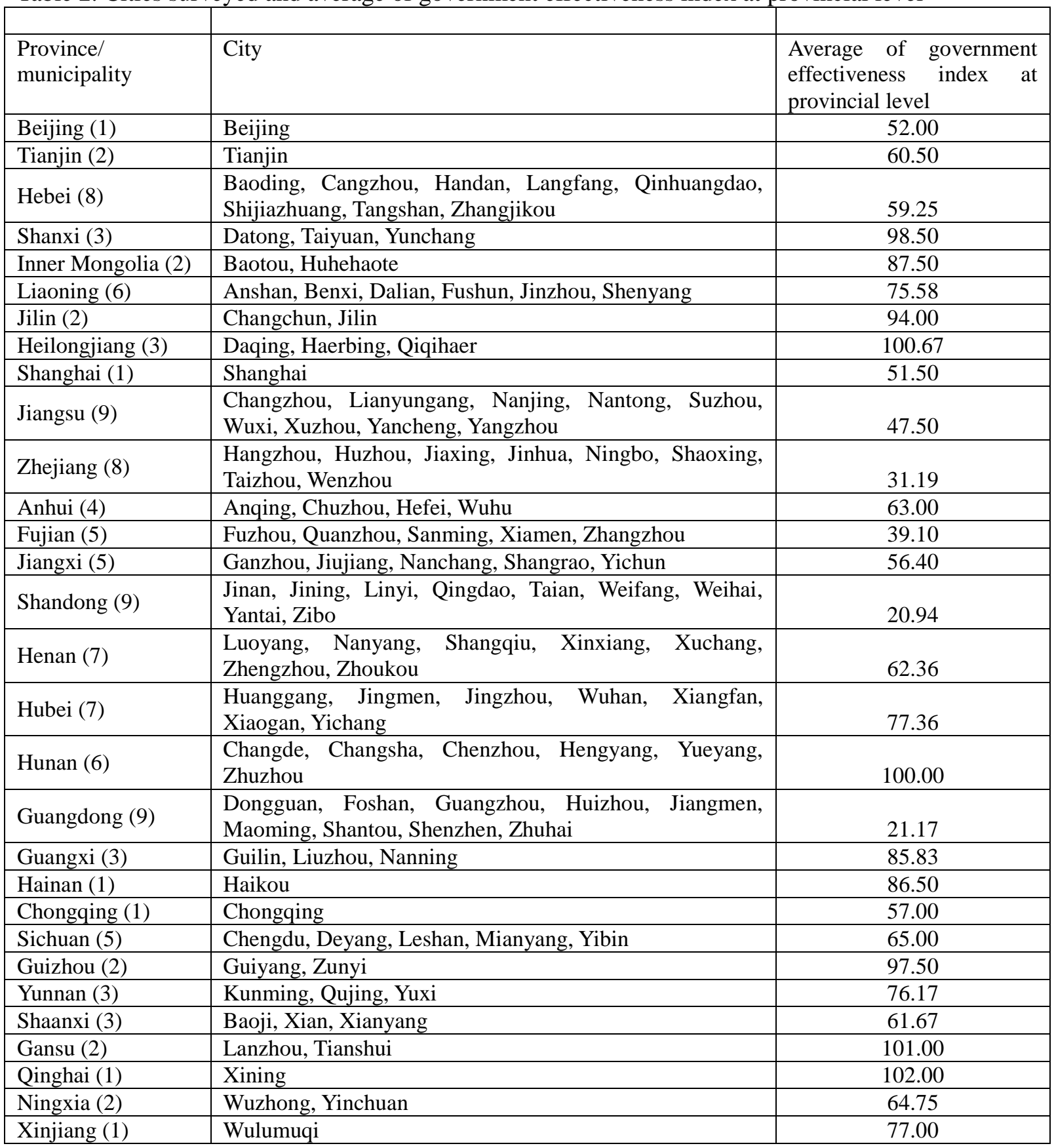

Source. Calculated by authors based on World Bank (2006); A smaller index value indicates higher level of government effectiveness. 
Table 3. Descriptive statistics and correlation matrix ${ }^{\mathrm{a}, \mathrm{b}}$

\begin{tabular}{|c|c|c|c|c|c|c|c|c|c|c|}
\hline & Mean & S.D. & Min. & Max. & (1) & (2) & (3) & (4) & (5) & (6) \\
\hline (1) Claim $_{i t}$ & 3.331 & 4.763 & 0 & 29.664 & 1.000 & & & & & \\
\hline (2) Effect $_{i t}$ & 69.098 & 23.245 & 20.944 & 102 & -0.610 & 1.000 & & & & \\
\hline (3) $\ln F F E_{\text {number, it }}$ & 8.436 & 1.409 & 4.812 & 11.498 & 0.527 & -0.709 & 1.000 & & & \\
\hline (4) $\ln G R P_{i t}$ & 8.785 & 1.016 & 5.797 & 10.952 & 0.508 & -0.533 & 0.849 & 1.000 & & \\
\hline (5) $\ln$ Patent $_{i t}$ & 3.333 & 4.541 & 0.045 & 25.067 & 0.722 & -0.669 & 0.706 & 0.570 & 1.000 & \\
\hline (6) Open & 34.312 & 42.913 & 3.572 & 174.968 & 0.419 & -0.569 & 0.652 & 0.356 & 0.680 & 1.000 \\
\hline
\end{tabular}

${ }^{\text {a }} \mathrm{N}=330$.

${ }^{\mathrm{b}}$ All correlation coefficients are significant at $p<0.001$. 
Table 4. Estimation results: Effects of governance effectiveness and FDI on infringement claims

\begin{tabular}{|c|c|c|c|c|c|c|}
\hline $\begin{array}{l}\text { Dependent variable: } \\
\text { Claim }_{i t}\end{array}$ & $\begin{array}{c}\text { Model } 1 \\
\text { (Random effects) }\end{array}$ & $\begin{array}{c}\text { Model } 2 \\
\text { (Random effects) }\end{array}$ & $\begin{array}{c}\text { Model } 3 \\
\text { (Hausman-Taylor) }\end{array}$ & $\begin{array}{c}\text { Model } 4 \\
\text { (Hausman-Taylor) }\end{array}$ & $\begin{array}{c}\text { Model } 5 \\
\text { (Fixed effects) }\end{array}$ & $\begin{array}{c}\text { Model } 6 \\
\text { (Hausman-Taylor) }\end{array}$ \\
\hline \multicolumn{7}{|l|}{ Independent Variables } \\
\hline Effect $_{i, 2006}$ & $0.037[0.028]$ & $0.448^{* * *}[0.103]$ & $-0.004[0.039]$ & $0.387 * * *[0.163]$ & & $1.948 * * *[0.727]$ \\
\hline Effect $_{i, 2006}^{2}$ & & $-0.003 * * *[0.001]$ & & $-0.003 * * *[0.001]$ & & $-0.013 * * *[0.005]$ \\
\hline $\ln F F E_{\text {number, it }}$ & & & & & $0.452[0.503]$ & $-1.387[4.288]$ \\
\hline $\ln F F E_{\text {number, } i t}^{2}$ & & & & & & $-0.220[0.146]$ \\
\hline$E f f e c t * \ln F F E_{\text {number }, i t}$ & & & & & & $0.142 * *[0.070]$ \\
\hline$E f f e c t^{2} * \ln F F E_{\text {number, }, t}$ & & & & & & $-0.001 * *[0.0004]$ \\
\hline \multicolumn{7}{|l|}{ Control Variables } \\
\hline $\ln G R P_{i t}$ & $1.580^{* *}[0.680]$ & $1.244 * *[0.602]$ & $3.284 * * *[1.170]$ & $2.265^{* *}[1.126]$ & & \\
\hline Patent $_{i t}$ & $0.204 * * *[0.069]$ & $0.177 * * *[0.068]$ & $0.155^{* *}[0.070]$ & $0.146^{* *}[0.070]$ & $0.175 * *[0.069]$ & $0.196 * * *[0.067]$ \\
\hline Open $_{i t}$ & $0.024 * *[0.010]$ & $0.018 * *[0.009]$ & $0.030^{* * *}[0.011]$ & $0.026 * * *[0.010]$ & $0.039 * * *[0.013]$ & $0.026^{* *}[0.012]$ \\
\hline Constant & $-8.053[6.605]$ & $7.264[6.770]$ & $-24.41 * *[11.19]$ & $-5.647[11.950]$ & $-2.039[3.868]$ & $56.60 *[33.132]$ \\
\hline Wald $\mathrm{Chi}^{2}$ & $62.38 * * *$ & $95.48 * * *$ & $50.49 * * *$ & $65.06^{* * *}$ & & $66.60 * * *$ \\
\hline F-Statistics & & & & & $1.67 *$ & \\
\hline $\mathrm{R}^{2}$ & 0.485 & 0.635 & & & 0.337 & \\
\hline
\end{tabular}

$\dagger \mathrm{N}=330$

$\dagger$ Significance levels: $* p<0.10, * * p<0.05, * * * p<0.01$.

$\dagger \dagger$ Numbers in [ ] are standardized errors. 
Table 5. Estimation results: Effects of government effectiveness on FDI

\begin{tabular}{|c|c|c|c|c|c|}
\hline & $\begin{array}{c}\text { Model } 1 \\
\text { (Fixed effects) }\end{array}$ & $\begin{array}{c}\text { Model 2 } \\
\text { (Fixed effects) }\end{array}$ & $\begin{array}{c}\text { Model } 3 \\
\text { (Hausman-Taylor) }\end{array}$ & $\begin{array}{c}\text { Model } 4 \\
\text { (Hausman-Taylor) }\end{array}$ & $\begin{array}{c}\text { Model } 5 \\
\text { (Hausman-Taylor) }\end{array}$ \\
\hline \multicolumn{6}{|l|}{ Independent Variables } \\
\hline Claim $_{\text {it }}$ & $0.004[0.007]$ & $0.020 *[0.012]$ & & $0.004[0.007]$ & $0.020 *[0.012]$ \\
\hline Claim $_{i t} \times$ Coast & & $-0.024^{\#}[0.015]$ & & & $-0.024 *[0.014]$ \\
\hline Effect $_{i, 2006}$ & & & $0.021 * * *[0.005]$ & $0.005^{* * *}[0.007]$ & $0.023^{* * *}[0.005]$ \\
\hline \multicolumn{6}{|l|}{ Control Variables } \\
\hline $\ln G R P_{i t}$ & $0.477 * * *[0.031]$ & $0.470 * * *[0.032]$ & $0.485^{* * *}[0.032]$ & $0.484 * * *[0.032]$ & $0.478 * * *[0.032]$ \\
\hline Patent $_{i t}$ & $-0.008[0.008]$ & $-0.007[0.008]$ & $-0.005[0.008]$ & $-0.006[0.008]$ & $-0.004[0.008]$ \\
\hline Open $_{i t}$ & $0.009 * * *[0.001]$ & $0.010 * * *[0.001]$ & $0.010 * * *[0.001]$ & $0.010 * * *[0.001]$ & $0.010 * * *[0.001]$ \\
\hline Constant & $3.886 * * *[0.275]$ & $3.933 *[0.276]$ & $5.333 * * *[0.477]$ & $5.315 * * *[0.479]$ & $5.429 * * *[0.487]$ \\
\hline F-statistics/Wald $\mathrm{Chi}^{2}$ & $97.93 * * *$ & $91.62 * * *$ & $1365.85^{* * *}$ & $1362.39 * * *$ & $1317.371 * * *$ \\
\hline $\mathrm{R}^{2}$ & 0.836 & 0.823 & & & \\
\hline
\end{tabular}

